\title{
Kritička teorija međunarodnih odnosa i neorealizam
}

\author{
Damir Mladić*
}

\begin{abstract}
Sažetak
Autor u ovom članku uspoređuje kritičku teoriju međunarodnih odnosa Andrewa Linklatera i neorealizam Kennetha Waltza. Taj je odnos analiziran u prvom redu pod vidom etike, a u manjem dijelu se osvrće i na različitost pristupa međunarodnim problemima. Budući da Linklater u nekoliko navrata napominje da je kritička teorija međunarodnih odnosa superiorna strukturalnomu realizmu ili neorealizmu, autor ovoga članka nastoji otkriti ima li opravdanih razloga za takvu tvrdnju.
\end{abstract}

Ključne riječi: kritička međunarodna teorija; neorealizam; etika; politička zajednica; emancipacija

\section{Uvod}

Kritička teorija međunarodnih odnosa ozbiljno shvaća ulogu etike u međunarodnim odnosima. Za razliku od realističke škole, koja moralu daje malu ili gotovo nikakvu ulogu u području međunarodnih odnosa, kritička teorija smatra da postoje dobri izgledi za stvaranje »etičke vanjske politike i novih oblika političke zajednice« (Linklater, 1998, 16). ${ }^{1}$ Štoviše, Linklater smatra etička pitanja najvažnijim pitanjima u međunarodnim odnosima. No, kritička teorija međunarodnih odnosa nije idealistički naivna: ona ne zanemaruje ulogu moći u postojećim političko-socijalnim aranžmanima. Ta postojeća političko-socijalna struktura postavlja ograničenja, odnosno smanjuje ili povećava vjerojatnost poželjne transformacije međunarodnih odnosa. Ostvarivost utopije ovisi o kontekstu u kojem bi se željena transformacija trebala dogoditi: u različitim kontekstima različite vrste transformacija međunarodne politike postaju više ili manje vjerojatnima. Danas je, primjerice, vjerojatnost transformacije postojećih političko-društvenih

\footnotetext{
* Doc. dr. sc. Damir Mladić, Libertas međunarodno sveučilište. Adresa: Trg J. F. Kennedyja 6b, 10000 Zagreb, Hrvatska. ORCID iD: https://orcid.org/0000-0001-5546-6332.

E-adresa:dmladic@libertas.hr

1 Citate je s engleskoga jezika preveo autor članka.
} 
struktura u svijet bez dominacije puno veća nego što je to bila prije stotinjak godina. Razlog je tomu promjena koju je sa sobom donijela globalizacija. Proces globalizacije, pogotovo u pogledu slabljenja suverene države i više razine osjetljivosti na kulturne različitosti, Linklateru daje nadu da više nećemo ponovo ponavljati iste pogreške iz prošlosti te da međunarodni odnosi mogu i trebaju biti drukčiji. Prema kritičkim teoretičarima, ništa se u međunarodnoj politici, kao i u općenito u politici, ne bi trebalo uzeti zdravo za gotovo, kao nešto unaprijed zadano i nepromjenjivo. To ne znači da smijemo zanemariti postojeće stanje međunarodne politike. Transformacije se ne događaju u vakuumu koji nastanjuju apstraktni ljudi, nego u konkretnom svijetu specifičnih političkih, socijalnih i kulturnih svojstava, kao i konkretnim ljudima sa specifičnim skupovima vjerovanja i ciljeva. Ako se želi stvoriti svijet slobodnih i jednakih, emancipiranih ljudi, onda svaki proces transformacije mora uzeti u obzir sva ta specifična stanja postojećega svijeta.

Pregled Linklaterove kritičke teorije međunarodnih odnosa, kao i svake druge teorije, zahtijeva pojednostavljivanje. U tu svrhu korisno je predstaviti Linklaterovu kritičku teoriju međunarodnih odnosa kao vrstu globalne političke teorije s tri elementa: 1. Vizija moralno poželjnoga svijeta u kojem ne postoji nikakav oblik dominacije i iskorištavanja: ostvarenje ideje univerzalne komunikacijske zajednice jednakih (etika); 2. Analiza postojećega svijeta politike definiranoga pomoću socijalnih silnica koje utječu na međunarodne odnose (sociologija); 3. Način nenasilne transformacije postojeće političke zajednice u moralno poželjni svijet putem dijaloga i procesa civiliziranja, s tim da se u obzir moraju uzeti i postojeća ograničenja (prakseologija).

Za kritičku teoriju međunarodnih odnosa bolji je onaj svijet koji smanjuje ograničenja ljudskoj slobodi. To je svijet bez ikakvoga oblika dominacije, odnosno svijet u kojem ljudi mogu biti slobodni koliko je god to moguće, a da pritom ne dominiraju nad drugim ljudima. Sve prošle, sadašnje i buduće političke, socijalne, kulturne i psihološke strukture koje podržavaju dominaciju, opresiju i eksploataciju te bilo kakvu drugu vrstu kontrole jedne grupe ljudi nad drugima trebaju biti razotkrivene i transformirane u manje ograničavajuće i manje štetne strukture. U tome veliku ulogu ima i proces civiliziranja, ili »razvoj socijalnih aranžmana u kojima djelovatelji mogu zadovoljiti svoje potrebe bez da 'unište, frustriraju, ponižavaju ili na neki drugi način štete jedni drugima' " (Linklater, 2005, 142), koji treba biti nastavljen u nedogled, jer će se gotovo uvijek pojavljivati novi oblici dominacije i nanošenja štete. Isto tako, postojeće isključive političke zajednice - suverene države - podržavaju dominaciju. Kako bismo započeli transformaciju postojećih isključivih (ekskluzivnih) političkih zajednica u uključive (inkluzivne) političke zajednice, potrebno je više znati o postojećoj političkoj i socijalnoj strukturi te o postojećem poretku i raspodjeli moći. Sljedeći korak bio bi otkriti kako postojeći politički i socijalni aranžmani ograničavaju ljudsku slobodu, kako podupiru dominaciju i opresiju, te kako ograničavaju naše opcije stvaranja manje opresivnoga svijeta. Potrebno je razumjeti naš povijesni trenutak, duh našega vremena, razumjeti gdje sad stojimo, našu kontingenciju, položaj, 
uvjete i ograničenja moguće promjene, te prilagoditi naše ciljeve toj stvarnosti. Za stvaranje svijeta slobodne i jednake etičke komunikativne zajednice potreban je kontinuirani dijalog u kojem pojedinci imaju pravo glasa kod donošenja odluka koje mogu utjecati na njihov život. Ukratko, kritička teorija međunarodnih odnosa mora predložiti ostvarivu globalnu utopiju uzimajući u obzir postojeći međunarodni politički sustav: ona je vrsta samo-refleksivnoga utopizma koji je u potrazi za u praksi ostvarivim oblikom međunarodne politike u kojem nema nijedne vrste dominacije.

Linklater se često osvrće na neorealizam, kao i na osnovne pojmove realizma poput anarhije, samopomoći i ravnoteže moći. Što i nije čudno, jer je neorealizam jedna od utjecajnijih, ako ne i najutjecajnija škola međunarodnih odnosa. Čini se da se od objave neorealističkoga prvijenca, Waltzove knjige Theory of International Politics ("Teorija međunarodne politike") 1979. godine, velik broj akademskih rasprava vrti upravo kao odgovor, kritika ili daljnji razvoj ideja iznesenih u tom djelu. Kako bismo razumjeli srž problema i razliku između neorealizma i kritičkih teorija međunarodnih odnosa, potrebno je ukazati na njihove različite osnovne pojmove i različite pristupe pojavama u međunarodnim odnosima. U Tablici 1 slijedi usporedba Waltzove i Linklaterove teorije.

Tablica 1. Usporedba Waltzova neorealizma i Linklaterove kritičke teorije međunarodnih odnosa

Table 1. A comparison of Waltz's neorealism and Linklater's critical theory in international relations

\begin{tabular}{|l|l|}
\hline \multicolumn{1}{|c|}{ Neorealizam (Waltz) } & \multicolumn{1}{|c|}{ Kritička teorija (Linklater) } \\
\hline $\begin{array}{l}\text { Nema previše mjesta za etiku u } \\
\text { međunarodnim odnosima. Naglasak je } \\
\text { na partikularizmu nacionalnih interesa. }\end{array}$ & $\begin{array}{l}\text { Etički univerzalizam i poštivanje } \\
\text { kulturnih različitosti važan su dio } \\
\text { međunarodnih odnosa. }\end{array}$ \\
\hline Deskriptivna, pozitivistička metoda. & $\begin{array}{l}\text { Normativna, sociološka i } \\
\text { prakseološka metoda. }\end{array}$ \\
\hline $\begin{array}{l}\text { Distribucija moći u anarhijskom sustavu } \\
\text { određuje ponašanje država. }\end{array}$ & $\begin{array}{l}\text { Mnoštvo različitih sila, uključujući i } \\
\text { društvene sile, određuju ponašanje } \\
\text { političkih zajednica. }\end{array}$ \\
\hline $\begin{array}{l}\text { Analiza usredotočena na međunarodni } \\
\text { sustav: zanemaruje događaje unutar } \\
\text { same države. Antiredukcionistički stav } \\
\text { - unutarnja stanja država se mijenjaju, } \\
\text { ali ponašanje država kroz povijest slijedi } \\
\text { isti obrazac. }\end{array}$ & $\begin{array}{l}\text { Analiza usredotočena na jedinicu } \\
\text { međunarodnoga sustava: pomoću } \\
\text { razumijevanja povijesti i tekućega } \\
\text { stanja političke zajednice, možemo } \\
\text { transformirati međunarodne odnose. }\end{array}$ \\
\hline $\begin{array}{l}\text { Pretpostavlja da je država stalna i } \\
\text { prirodna politička organizacija i ima } \\
\text { isključivu narav. }\end{array}$ & $\begin{array}{l}\text { Država se može promijeniti te nije } \\
\text { prirodna tvorevina. Moderna država, } \\
\text { kao proizvod povijesti, može biti } \\
\text { zamijenjena nekim inkluzivnijim } \\
\text { političkim aranžmanima u } \\
\text { budućnosti. }\end{array}$ \\
\hline
\end{tabular}




\begin{tabular}{|c|c|}
\hline $\begin{array}{l}\text { Vlast države je najviši oblik autoriteta u } \\
\text { međunarodnim odnosima. }\end{array}$ & $\begin{array}{l}\text { Postoje drugi oblici autoriteta koji } \\
\text { nadilaze državnu vlast. }\end{array}$ \\
\hline $\begin{array}{l}\text { Anarhijski međunarodni sustav je stalan } \\
\text { i određuje obrasce ponašanja država. }\end{array}$ & $\begin{array}{l}\text { Anarhijski međunarodni sustav } \\
\text { može se promijeniti pomoću } \\
\text { transformacije isključivih političkih } \\
\text { zajednica kakve su suverene države. }\end{array}$ \\
\hline $\begin{array}{l}\text { Biti građanin, odnosno državljanin } \\
\text { (država) znači imati posebnu moralnu } \\
\text { obvezu prema svojim sugrađanima, } \\
\text { naciji, državi - i ta moralna obveza je } \\
\text { važnija nego moralna obveza prema } \\
\text { ostalim ljudima. }\end{array}$ & $\begin{array}{l}\text { Biti čovjek (kozmopolitizam) } \\
\text { važnije je jer nacionalne granice } \\
\text { nemaju moralnu važnost. Imamo } \\
\text { iste moralne obveze i prema svojim } \\
\text { sugrađanima i prema drugim } \\
\text { ljudima. }\end{array}$ \\
\hline $\begin{array}{l}\text { Povijest se ponavljanja, a čovjek ostaje } \\
\text { više-manje isti. }\end{array}$ & $\begin{array}{l}\text { Povijest se ne ponavlja - možemo } \\
\text { govoriti o različitom kontekstu u } \\
\text { kojem čovjek djeluje i koji na njega } \\
\text { utječe te ga mijenja. }\end{array}$ \\
\hline $\begin{array}{l}\text { Kritika kritičkih teorija međunarodnih } \\
\text { odnosa: nedostaje podataka i } \\
\text { istraživanja koji bi poduprli njezine } \\
\text { tvrdnje. Primjerice, nedostaju podatci } \\
\text { koji podupiru vjeru u globalnu ljudsku } \\
\text { solidarnost i altruizam. }\end{array}$ & $\begin{array}{l}\text { Kritika neorealizma: nedostaje } \\
\text { mu primjereno objašnjenje } \\
\text { modernih političkih zajednica, a što } \\
\text { ograničava njihovu viziju o mogućim } \\
\text { transformacijama međunarodnih } \\
\text { odnosa. }\end{array}$ \\
\hline Glavna preokupacija: sigurnost & Glavna preokupacija: emancipacija \\
\hline $\begin{array}{l}\text { Problem solving teorija: kako postojeći } \\
\text { međunarodni politički poredak može } \\
\text { riješiti određeni problem. Uzima } \\
\text { postojeći politički poredak zdravo za } \\
\text { gotovo. }\end{array}$ & $\begin{array}{l}\text { Kritička teorija: kako je postojeći } \\
\text { međunarodni politički poredak } \\
\text { nastao i kako ga promijeniti. Smatra } \\
\text { da je postojeći politički poredak } \\
\text { rezultat povijesnoga razvoja i uvijek } \\
\text { u mijeni. } \\
\end{array}$ \\
\hline $\begin{array}{l}\text { Instrumentalna racionalnost - kako } \\
\text { ostvariti nacionalne interese (preživjeti) } \\
\text { u anarhijskoj okolini. }\end{array}$ & $\begin{array}{l}\text { Viša racionalnost - kako premostiti } \\
\text { jaz između zbilje i mogućnosti, } \\
\text { između postojećih političko- } \\
\text { društvenih struktura i svijeta } \\
\text { emancipacije. }\end{array}$ \\
\hline
\end{tabular}

Prema tablici vidljivo je da su predmeti i paradigme razmišljanja neorealizma i kritičkih teorija u mnogim stvarima različite, što za posljedicu ima i različitu metodologiju. Realisti se bave mogućnostima djelovanja država u zadanim okolnostima, a kritički teoretičari svoju pozornost usmjeravaju prema sasvim drukčijim pitanjima, odnosno prema mogućnosti poboljšanja svijeta proširivanjem granica naših političkih i moralnih zajednica. Iako Linklaterove analize postojećih odnosa moći mogu biti zanimljive neorealistima, sljedeći korak na kojem insistiraju kritičke teorije, naime normativni korak u smjeru poželjnih promjena međunarodnoga sustava, često je neprihvatljiv u očima realista. Zbog tih razlika dolazi do nerazumijevanja između njih, odnosno neorealisti ne vide baš previše koristi od bavljenja temama koje su središnje kod kritičkih teorija, a kritički teoretičari zamjeraju neorealistima pomanjkanje širega razmišljanja o problemima 
međunarodnih odnosa. Kritički teoretičari rijetko će pronaći sugovornika među neorealistima, odnosno neorealisti neće baš razumjeti o čemu kritički teoretičari govore. S druge strane, čini se da kritički teoretičari poput Linklatera ne samo da dobro razumiju neorealizam, nego su spremni upustiti se u raspravu s njim. No ti prigovori i kritike često nailaze na neorealistički zid šutnje.

Kritička teorija međunarodnih odnosa sebe ponekad predstavlja kao teoriju koja je u prvom redu etički, ali i u sveukupnom pristupu, superiorna neorealističkoj teoriji međunarodnih odnosa. U čemu se sastoji ta samoproglašena superiornost kritičke teorije? Prva je pretpostavka ovoga članka da je tu riječ o etičkoj superiornosti kritičke teorije nad neorealizmom. Razlog za takav stav o etičkoj superiornosti kritičke teorije vjerojatno je taj što kritička teorija, puno više no neorealizam, naglašava ulogu etike u međunarodnim odnosima. Druga je pretpostavka ovoga članka da se ta superiornost odnosi na superiornost općega pristupa kritičke teorije problemima međunarodnih odnosa. Razlog je za takav stav kritičke teorije vjerojatno taj što kritička teorija samu sebe smatra puno obuhvatnijim pristupom međunarodnim odnosima od neorealizma te nastoji ne samo opisati postojeće stanje, nego i nadvladati jaz između postojećih međunarodnih političkih struktura i etički poželjnih političkih struktura. Na temelju te dvije pretpostavke slijede dva pokušaja odgovora na pitanja o tome ima li Linklater opravdanih razloga tvrditi da je kritička teorija u prvom redu etički, a i u općem pristupu problemima međunarodnih odnosa, superiorna neorealizmu.

\section{Etička superiornost kritičke teorije međunarodnih odnosa?}

U prvom dijelu članka razmatra se opravdanost tvrdnje o etičkoj superiornosti kritičke teorije međunarodnih odnosa, pogotovo u odnosu na neorealizam.

\subsection{Promicanje emancipacije}

Opravdanje tvrdnje o etičkoj superiornosti kritičke teorije nad neorealizmom moglo bi započeti tvrdnjom o etičkoj superiornosti krajnjega cilja kritičkih teorija, odnosno pomoću ljudske emancipacije. Ta ideja emancipacije razlikuje kritičku teoriju od svih ostalih teorija međunarodnih odnosa. Neorealistička tradicija, primjerice, smatra da je najvažniji cilj teorije međunarodnih odnosa odgovoriti na pitanje o tome kako osigurati opstanak države u anarhijskom sustavu država. Kritička teorija, s druge strane, smatra da je promicanje ljudske emancipacije najvažniji cilj. Emancipacija znači autonomiju i samoodređenje čovjeka, ali pod ograničavajućim uvjetom da se ta autonomija i samoodređenje ne ostvaruju na štetu drugih. To je borba protiv bilo koje vrste dominacije i kontrole jedne grupe ljudi nad drugim ljudima (Devetak, 2009, 168). Glavni cilj kritičke teorije, odnosno promicanje emancipacije, pogotovo marginaliziranih grupa, temelj je opravdanja njezine etičke superiornosti (Linklater, 1990, 8). Nadalje, ta tvrdnja o etičkoj superiornosti poduprta je stalnim korištenjem etičkoga jezika i moralnih normi, kao i moralnih osuda, koje kritički teoretičari koriste u analizi postojeće 
međunarodne političke zbilje. Oni, primjerice, otkrivaju moralne nesavršenosti modernoga sustava država te smatraju da su te moralne nesavršenosti same po sebi dovoljan razlog za promjenu toga sustava. Ako se na taj način razumiju kritičke teorije, kao potraga za moralnim manama političkoga sustava, onda ne treba čuditi stav kritičara kritičkih teorija koji upozoravaju na to da kritičke teorije često zanemaruju važne probleme poput sigurnosti i stabilnosti međunarodnoga sustava. Održavanje postojećega, moralno manjkavoga međunarodnoga sustava, pa čak i ako je on stabilan, čini se da nije prioritet za kritičku teoriju. Sam takav sustav (moralno manjkav sustav je onaj u kojem postoji neka vrsta dominacije) potrebno je mijenjati, a ne ga održavati raznim rješenjima za probleme unutar toga sustava, kao što to čine neorealizam ili neoliberalizam. Kritička teorija, dakle, u potrazi je za boljim i pravednijim sustavom, a ne za boljim rješenjima unutar postojećega sustava država. Iako se kritički teoretičari i neorealisti slažu oko toga da moralno savršeni svjetovi starih utopista nisu ostvarivi, kritički teoretičari ipak sugeriraju da bi se ovaj svijet dominacije mogao promijeniti te da je etički poželjan svijet dijaloga i pristanka vjerojatno ostvariv. U tom svijetu dijaloga i pristanka moguće je »približiti se normativnomu idealu univerzalne komunikativne zajednice « (Linklater, 1998, 8). Čini se, barem na prvi pogled, da su krajnji ciljevi kritičkih teorija etički poželjniji od ciljeva neorealizma i neoliberalizma.

\subsection{Prioritet etike nad politikom}

Ako se političke ciljeve i sredstva procjenjuje etičkim standardima, onda se može reći da etika ima veću važnost od politike. U tom slučaju moglo bi se reći da je kritička teorija međunarodnih odnosa etički superiorna neorealizmu - jer neorealizam, u većoj ili manjoj mjeri, zastupa autonomiju međunarodne političke sfere. No, naglašavanje uloge etike u međunarodnoj politici nije nova stvar. Liberali, a pogotovo idealisti, imali su često gotovo propovjedničku revnost u zagovaranju mira, harmonije i etike u međunarodnim odnosima. Po čemu se, dakle, kritička teorija razlikuje od svih ostalih teorija koje zagovaraju neku vrstu prioriteta etike nad međunarodnom politikom?

\subsubsection{Etički univerzalizam i poštivanje različitosti}

Za kritičke teorije, etički univerzalizam i poštivanje različitosti temelj je međunarodne politike. Razlika između većine teorija međunarodnih odnosa koje drže do etičkih pitanja i kritičke teorije u tome je što kritička teorija ne daje nikakav univerzalni etički kodeks s unaprijed definiranim skupom moralnih normi i vrijednosti. Univerzalni moralni zakon trebao bi biti rezultat dijaloga među jednakima, a ne nešto što se unaprijed daje ljudima. Prihvaćajući dijalog kao izvor etičkoga univerzalizma, kritička teorija međunarodnih odnosa želi izbjeći bilo koju vrstu dominacije nekoga već postojećega morala, pogotovo dominaciju morala Zapada. Iako kritički teoretičari, ili barem oni tako vjeruju, ne daju nikakav specifični sadržaj skupu etičkih vrijednosti i normi za te etički poželjne komunikativne zajednice jednakih (osim proceduralnih uvjeta), ipak se čini da 
vrijednosti slobode i jednakosti jesu integralni dio etike diskursa. Te prešutne liberalne vrijednosti Zapada mogu predstavljati velike smetnje u međunarodnim odnosima, jer neliberalna društva većinom ne priznaju te vrijednosti kao univerzalne.

\subsubsection{Inkluzivnije političke zajednice}

Za Linklatera inkluzivnije političke zajednice imaju utjecaj i na međunarodnu politiku. Progresivna moralnost inkluzivnijih političkih zajednica koje emancipiraju ljude transformiraju i svjetski poredak te političke životinje u njemu. Kritička teorija međunarodnih odnosa tvrdi da inkluzivnije političke zajednice mogu promijeniti kako postojeću međunarodnu anarhiju u suradničku i manje konfliktnu okolinu, tako i ljude koji u njima žive. Primjerice, ljudi su danas puno osjetljiviji na različitost i patnju "drugih". Postoje, dakle, dvije stvari koje se transformiraju stvaranjem inkluzivnijih političkih zajednica: ljudska narav (klasični realisti) i međunarodna anarhija (neorealisti). Te dvije datosti većina realističkih mislitelja smatra čvrstim i nepromjenjivim, ili barem ne nečim što se može uskoro promijeniti. Ljudska narav i međunarodna anarhija za realiste i neorealiste konstante su pomoću kojih se objašnjavaju događaji u međunarodnim odnosima. Pomoću nepromjenjive ljudske sebičnosti i anarhije međunarodnoga sustava realisti daju odgovor na pitanje zašto se međunarodna politika mora razumjeti kao natjecanje za moć. Primjerice, klasični realisti poput Hansa Morgenthaua smatraju da se države bore za moć jer čovjek po naravi ima neutaživu žeđ za dominacijom, a strukturalni realisti poput Kennetha Waltza smatraju da su zbog anarhijske strukture međunarodnoga sustava države prisiljene natjecati se za moć kako bi preživjele. Pitanje je kako bi to točno inkluzivnije političke zajednice mogle utjecati na ljudsko ponašanje (učiniti nas manje sebičnim ljudima) te umanjiti utjecaj anarhije na ponašanje država, osim ukinućem samih država i stvaranjem jedinstvene ljudske zajednice (što se čini, barem iz današnje perspektive, malo vjerojatnim).

\subsubsection{Moralna odgovornost država}

Kritički teoretičari vjeruju da postoji moralna odgovornost država po kojoj su one dužne promijeniti nepravedan svijet međunarodne politike. Prema Linklateru neorealističko vjerovanje u postojanost anarhije koja prisiljava države na sebično ponašanje glavni je razlog zašto je neorealizam kriv za »odrješenje država od moralne odgovornosti za razvoj praksa koje će stvoriti pravednije oblike svjetskih političkih organizacija« (Linklater, 1998, 19). Neorealizam, kao teorija rješavanja konkretnih problema postojećega međunarodnoga sustava, prema kritičkoj teoriji pogrešno prihvaća nepromjenjivost anarhije u međunarodnoj politici i zbog toga je i etički inferiornija teorija. Rješavanjem problema unutar takvoga nepravednoga međunarodnoga sustava neorealizam, ustvari, pomaže preživljavanju nepravednih međunarodnih struktura. Ako prihvatimo poznati Coxov argument da je znanje uvijek za nekoga i za neku svrhu (Cox, 1986), onda neorealizam, pomažući rukovođenje postojećim nepravednim svjetskim poret- 
kom, radi u interesu privilegiranih, odnosno u interesu velikih sila i svih ostalih dominantnih grupa, a samim time i protiv dominiranih, slabih država i marginaliziranih, siromašnih grupa (Linklater, 1998, 21). Neorealizam je, dakle, optužen za to da rješavajući konkretne svjetske probleme ustvari potpomaže postojeću nepravednu distribuciju moći i bogatstva u svijetu. Nadalje, zbog toga što podupire postojeći vestfalski sustav suverenih država, neorealizam i njegova teza o nepromjenjivosti anarhije i ljudske naravi, smatraju se smetnjom nadilaženju jaza između stvarnoga i moralno poželjnijega međunarodnoga sustava. Kao problem solving teorija neorealizam je, prema takvom shvaćanju, etički inferiornija teorija od kritičke teorije.

\subsection{Realniji pristup transformaciji političke zbilje i etička superiornost}

Potrebno je napomenuti da je to što kritičku teoriju međunarodnih odnosa čini drukčijom od ostalih idealističkih teorija i prihvaćanje "realnijega" pristupa postojećoj političkoj zbilji i procesima transformacije postojećih međunarodnih struktura. Cilj ostaje isti (razum može transformirati i kontrolirati strasti u univerzalnoj komunikativnoj zajednici), ali sredstva moraju biti modificirana u skladu s postojećim političkim, socijalnim, kulturnim i psihološkim praksama (kontekst i pravovremenost također su važni). Potrebno je vrijeme i strpljenje kako bi se izbjeglo svim zamkama konteksta postojećega političkoga svijeta i prevladavajućih vjerovanja. Treba dosta vremena i dijaloga te iskustva kako bi se modelirao novi moralni čovjek u novom svijetu. Taj način razmišljanja moguć je samo ako se čvrsto vjeruje da su ljudske prakse socijalno konstruirane i ako se dijeli Marxovo vjerovanje da »sve što je čvrsto jednom se rastvori u zrak te da nije vjerojatno da će budućnost biti slična prošlosti ili da će se ponoviti prošlost « (Linklater, 1998, 22).

\subsection{Modifikacija moderne države u smjeru veće inkluzivnosti}

Svijet bez marginaliziranih i potlačenih grupa ljudi ujedno je i inkluzivniji svijet. Kako bi se došlo do toga svijeta, treba se ili ukinuti ili modificirati moderna država - jer je ona ekskluzivna politička zajednica koja održava postojeći nepravedni međunarodni sustav koji priječi emancipaciju. No, kao što je Kant na primjeru Francuske revolucije bio upozoren na to kako ne nastaviti s razvojem moralne slobode, tako su i kritički teoretičari u novije doba imali primjer komunističkih režima koji im je pokazao kako to ne valja činiti. Zašto onda kritički teoretičari očekuju da je takva vrsta moralne i političke transformacije danas moguća? Što se toliko promijenilo a da bi dalo nadu u takve promjene u ovom svijetu u kojem još uvijek vlada materijalna oskudica? Linklater vjeruje da je došlo vrijeme za postavljanje temelja inkluzivnijemu svijetu. Jedan je razlog za takvo vjerovanje postojanje postvestfalske zone suradnje u svijetu, odnosno Europske unije. On vjeruje da postoji nada u manje nasilne međunarodne odnose jer se kontekst promijenio i vrijeme je sazrjelo. »Moderno društvo država možda može ispasti i prvo međunarodno društvo koje nije uništeno osvajanjima i rato- 
vima, nego mirno transformirano pomoću normativnih obveza za proširenjem moralnih i političkih granica zajednice« (Linklater, 1998, 9). Kako se to točno može učiniti? »Uključivanjem sustavno isključivanih u dijalog o načinima na koji društvene prakse i politike štete njihovim interesima«, a što je ključna etička obveza svakoga društva koje se želi promijeniti na taj način (Linklater, 1998, 7). Taj proces ima određenu moralnu privlačnost, iako daje obećanje o drugom putovanju bez nekoga posebnoga cilja na pameti, gdje će se uvijek otkrivati nešto novo kritizirajući ono staro.

\subsection{Osvrt na Linklaterovu tvrdnju o etičkoj superiornosti kritičke teorije međunarodih odnosa}

U prvom redu, treba se pitati koliko je takav Linklaterov pristup "realniji” od ostalih utopističkih pristupa? Iako je ponekad teško razlikovati između prirodnoga i kontingentnoga u ljudskim stvarima, čini se da kritičke teorije pretpostavljaju preveliku plastičnost ljudskih praksi, a što, kao što je poznato iz povijesti, može odvesti u neželjenom smjeru. Pogotovo ako promjene ne percipiramo kao slobodno odabrane promjene, nego kao nametanje u praksi neprovjerenih ideja. Čak i ako prihvatimo da je u prošlosti bilo puno zlouporabe pozivanja na "argument iz naravi", to jest na slučajeve kad su povijesno kontingentne i socijalno konstruirane pojave proglašavane prirodnim i nepromjenjivim činjenicama, čini se da, s druge strane, postoji opasnost nekontroliranoga nametanja samoproglašenih progresivnih rutina i vrijednosti postojećim zajednicama. Postoje slučajevi u kojima se i insistiranje na dijalogu te slobodi i jednakosti pojedinaca mogu percipirati kao izvana nametnute vrijednosti (primjerice, kao zapadne vrijednosti koje se nameću nezapadnim civilizacijama). Taj proces može biti dezorijentirajući i kontraproduktivan te može izazvati reakcije koje će još dodatno smanjiti ljudsku slobodu i autonomiju. Takva negativna reakcija moguća je i u slučajevima kad se govori o vjerojatno opravdanim temeljnim zahtjevima poput »prava na jednak pristup svim postupcima donošenja odluka « svih ljudi na čiji život te odluke utječu (Linklater, 2005, 142). Drugim riječima, etička se univerzalnost može, u nekim slučajevima, percipirati kao nepoželjna i izvana nametnuta.

Nadalje, rješavanje sigurnosnih problema postojećega svijeta također ima svoja etička opravdanja (nije dobro uništiti postojeće stabilne strukture u ime ideala emancipacije) i da kritička teorija nije nužno etički superiorna ostalim klasičnim teorijama međunarodnih odnosa samo zato jer se rukovodi čisto protokolarnim etičkim univerzalizmom i emancipacijom kao ciljem. Kao što je poznato iz povijesti, nekontrolirana i radikalna implementacija apstraktnih ideja i novih postupaka ljudskim zajednicama je povijest puna leševa.

Osim toga, transformacija političke zajednice može biti bolna i ne mora nužno rezultirati većom inkluzivnošću. Kako god bilo, čini se da je pozivanje na etiku vjerojatno najvažniji dio kritičke teorije međunarodnih odnosa. S jedne strane, moralni razvoj ljudske vrste i ljudske slobode važan je i tu Linklater daje svoj hvalevrijedan doprinos. S druge strane, čini se da kritička teorija u sebi uključuje zahtjeve ne samo prema transformaciji strukture političke zajednice, nego 
i prema transformaciji samoga čovjeka. Marksizam je, primjerice, očekivao da će čovjek prema svojim mogućnostima učiniti nešto za svoj kolektiv samo zbog moralnih nagrada, i da neće očekivati materijalne nagrade. Od socijalističkoga čovjeka se očekivala materijalna žrtva za dobro kolektiva, a nagrada je dolazila u obliku moralne satisfakcije. Kritička teorija međunarodnih odnosa, čini se, ne samo da traži od čovjeka odustajanje od dijela svojih materijalnih dobara, nego žrtvovanje i dijela svojega vlastitog identiteta. Drugim riječima, čovjek bi slobodno, iz moralnih razloga, trebao promijeniti svoje postojeće konkretne prakse, norme i vrijednosti. Riječ je, dakle, o prihvaćanju različitih “drugih” kao članova naše (univerzalne) moralne političke zajednice. Kao pripadnici neke političke zajednice, postojeći bi članovi trebali proširiti njihovu političku zajednicu preko nacionalnih i državnih granica (uključiti i prihvatiti one izvan tih granica u svoju zajednicu, a u isto vrijeme poštivati njihovu kulturnu različitost) dajući drugima politička prava sudjelovanja u dijalogu i procesu donošenja odluka o stvarima koje imaju utjecaja na njihov život. A to znači dajući im i pravo promijeniti život moralne i političke zajednice koja ih prihvaća, i to na način koji se ne može predvidjeti, a može se i zlorabiti. Tražeći od stabilne političke zajednice da učini taj skok, kritička teorija u velikoj mjeri zanemaruje mogućnosti zlouporabe dijaloga, kao i utjecaj nižih ljudskih strasti, kao što su zavist i strah (obilježja svih ljudi, ne samo neciviliziranih grupa). Zanemarivanje snage ljudskih strasti poput zavisti, mržnje i straha već je dalo i daje svoj obol u ideološkim ratovima. Uz to, briga o zahtjevima marginaliziranih skupina često za sobom donosi i instinkt za kažnjavanjem privilegiranih, bogatih, dominantnih grupa. Čini se da je u tom slučaju kažnjavanje postalo neka vrsta "samokažnjavanja" prema sljedećem naputku: emancipacijom marginaliziranih izliječit ćete se moralne tjeskobe koja vas tišti jer ste privilegirani i bogati. Traži se, dakle, od privilegirane grupe da svojevoljno prošire svoju političku zajednicu zbog moralnih razloga, žrtvujući time ne samo materijalna dobra, nego i prilagođavajući svoj identitet u interakciji s novim, drugim i drukčijim članovima svoje sve inkluzivnije zajednice. No pritom se očekuje da i jedni i drugi ignoriraju svoje osjećaje i strahove. Ta je vrsta zahtjeva, čini se, ponekad previše za krhku ljudsku narav. Ako je jedina nagrada koju možemo očekivati u obliku oslobođenja od moralne tjeskobe, oslobođenje od krivnje koja dolazi uz znanje o "patnji dalekoga stranca”, onda je vrlo teško očekivati da će ljudi slobodno i bez otpora prihvatiti takvo proširenje svoje zajednice. Kao što to povijest pokazuje: »Ne postoji povijesni primjer za takav altruizam na globalnoj razini« i vrlo je teško vidjeti kako se pomoću komunikacije ili dijaloga to može postići (Schweller, 1999, 148).

Linklater smatra da su moralni deficiti i moralna tjeskoba u svijetu, a pogotovo na Zapadu, posljedice sadašnjih moralnih i političkih normi, prema kojima mi pridajemo veću moralnu važnost državljanima naše države nego strancima. Naše obveze prema našim sugrađanima gotovo su uvijek jače nego naše obveze prema ostatku čovječanstva - a to nepravedno isključivanje ostalih budi nam osjećaj moralne manjkavosti. Kao rezultat kritike tekućega stanja moralnoga i političkoga razvoja, kritička teorija međunarodnih odnosa tvrdi da »univerzal- 
nost razvijenijega moralnoga zakona uključuje veću otvorenost prema drukčijemu i povećanu osjetljivost prema kulturnim različitostima te poštivanje istih. Moderni građani uče jezik transcendentnoga moralnoga zakona koji omogućuje kritiku zlouporabe nacionalne moći ili kulturnu aroganciju te čini mogućom viziju manje hijerarhijskoga međunarodnoga društva! (Linklater, 1998, 24). Prema tome, moralno neprihvatljivo djelovanje ima svoj izvor u postojećem političkom i društvenom poretku, koji je previše isključiv, previše štetan, previše neslobodan. U današnjem svijetu postoji previše kontrole, dominacije, tlačenja, isključivanja i sukoba. S druge strane, premalo je slobode, jednakosti, samo-određivanja, poštivanja kulturnih razlika i univerzalne solidarnosti. Kritička nam teorija kaže kako bismo trebali transformirati postojeći poredak i postojećega čovjeka te stvoriti bolji svijet.

No, iako je emancipacija kao cilj kritičke teorije poželjan, sredstva i načini na koji to želi postići, kao i uvjeti koji pritom moraju biti ispunjeni, mogu se, temeljem podataka o prošlim i sadašnjim stanjima, staviti u pitanje. Zbog toga što pred sebe stavlja teško ostvarive grube nacrte boljega i pravednijega svijeta, upitna je i sama etička superiornost kritičke teorije.

\section{Superiornost pristupa kritičke teorije međunarodnih odnosa problemima međunarodnih odnosa?}

U drugom dijelu članka ukratko se razmatra opravdanost tvrdnje o superiornosti kritičke teorije međunarodnih odnosa pod vidom općega pristupa međunarodnim odnosima, pogotovo u odnosu na neorealizam.

\section{1. "Viša racionalnost” kritičke teorije}

Iako Linklater uzima neorealizam kao početnu točku svojih rasprava, on vjeruje da je kritička teorija međunarodnih odnosa superiorna neorealizmu, i to ne samo etički, nego i u cjelokupnom pristupu međunarodnim odnosima. Prema Linklateru (1992) kritički je obrat »sljedeći stupanj razvoja u teorijama međunarodnih odnosa«. On će dati dublji i sveobuhvatniji pristup području međunarodnih odnosa nego što to daje plitka pozitivistička metoda neorealizma. Prema njemu Marx i Kant su »razvili kritičko-teorijski pristup političkoj zajednici koji je superioran neorealističkoj tezi da će se natjecanje i sukob između država nastaviti tako dugo dok međunarodno društvo bude anarhično (Linklater, 1998, 9). Taj je kritičko-teorijski pristup političkoj zajednici primjer »više racionalnosti napora kako bi se premostio jaz između zbilje i mogućnosti« (Linklater, 1998, 22). Jednostavna instrumentalna ili tehnička racionalnost neorealizma nije dovoljna za adekvatno objašnjenje političke zajednice te zbog toga skriva mogućnosti pozitivnih promjena postojećih nacionalnih ili globalnih političkih zajednica, u prvom redu suvremene države. 


\subsubsection{Projekt suvremene države}

Kritički teoretičari misle da Waltzov neorealizam uzima "zdravo za gotovo" suvremenu državu i međunarodnu anarhiju te time reducira objašnjenje međunarodnih odnosa na opisivanje ponavljajućih obrazaca ponašanja države. Ograničavajući sebe na taj način, neorealizam zanemaruje činjenicu da je suvremena država, kao moderna politička struktura, relativno novi izum, odnosno da država nije prirodni i stalni način političke organizacije, nego proizvod povijesti, rezultat povijesnih procesa koji su ju stvorili. Ako je moderna država rezultat mnoštva različitih procesa, onda je moguće zamisliti da, pod drukčijim uvjetima i zahvaljujući drukčijim procesima, ta država može biti transformirana u novu političku konfiguraciju. S druge strane, Linklater priznaje da je u vestfalskom dobu moderna država najuspješnija u konsolidiranju svoje moći i da je pobijedila suparnike poput gradova-država i carstva. Prema Linklateru, ovaj 350 godina stari način političke organizacije u suverenu državu bio je uspješan u postizanju pet monopola ili jedinih prava na (1) kontrolu instrumenata nasilja, (2) oporezivanje građana, (3) političku vjernost građana, (4) donošenje presuda u razmiricama građana i (5) predstavljanje političke zajednice u međunarodnom društvu. Rezultat te monopolizacije moći homogenizacija je društva i učvršćivanje nacionalnih granica, što više-manje znači uspješno odvajanje "nas" i “vas", onih koji su unutra i onih koji su vani. Moderna je država, dakle, isključiva politička organizacija koja stvara i njeguje sentimente poput "mi protiv ostatka svijeta". Unatoč tomu, u velikoj mjeri uspješnomu, projektu totalizacije i stvaranja homogenih nacionalnih zajednica, Linklater vjeruje da taj projekt države nije u potpunosti dovršen, kao što to prikazuju neorealisti. Ta nepotpunost projekta totalizacije otvara mogućnosti za stvaranje novih oblika političke organizacije, usmjeravanjem procesa racionalizacije u drukčijem smjeru, vjerojatno prema svijetu u kojem postoji viša vlast od državne. Ali iz činjenice da je moderna država proizvod povijesti ne slijedi da će država nestati. Čini se da Linklater vjeruje kako proces globalizacije mijenja isključivi karakter države i da nam usredotočenost na »otkrivanje prvih znakova strukturalnoga propadanja i društvene transformacije « (Linklater, 1998, 22) može dati bolji uvid u, do sad, skrivene mogućnosti transformacije sustava država.

Nadalje, prema kritičkoj teoriji, neorealizam obično zanemaruje sile koje djeluju unutar države, usredotočujući se samo na međudržavne odnose i uzimajući moderne države kao "crne kutije" koje sve imaju slične funkcije, ali različite kapacitete za obavljanja tih funkcija. Neorealisti promatraju distribuciju moći u sustavu država i kako ta distribucija moći utječe na ponašanje tih država. Države, ili glavni politički entiteti s jedinstvenom voljom i interesima, prisiljene su ponašati se na određeni način zbog anarhičnoga međunarodnoga sustava. Zanemarujući, ali ne u potpunosti odbacujući, mogućnost da buduće globalno društvo može biti »uređeno slobodno odabranim moralnim načelima koja povećavaju autonomiju svih ljudi« (Linklater, 1998, 22), neorealisti reduciraju međunarodne odnose na natjecanje za moć i na traženje najboljih načina na koje možemo održati stabilnost i red u ovom svijetu. Za kritičku teoriju takvo metodološko samoograniča- 
vanje neorealizma čini se previše konzervativno i besplodno, i to zbog toga što ne dopušta traganje za političkim strukturama koje nadilaze nacionalni interes i međunarodnu anarhiju. Kako bismo razvili globalne političke strukture koje ne ograničavaju ljudsku slobodu i jednakost, koje nisu nacionalno isključive, potrebno nam je bolje i dublje razumijevanje zajednice.

\subsection{Tri dimenzije kritičkoga pristupa međunarodnim odnosima}

Za razliku od ograničene pozitivističke metode neorealizma, kritički je pristup međunarodnim odnosima puno širi te u sebi uključuje tri dimenzije: normativnu, sociološku i prakseološku. Normativna dimenzija kritizira moralne manjkavosti moderne, suverene, vestfalske države. Sociološka dimenzija ispituje izvore i evoluciju suverene države, kao i vestfalskoga sustava država, te otkriva oblike štete koji uz njih idu. Prakseološka dimenzija traga za praktičnim mogućnostima ponovnoga stvaranja međunarodne politike koja bi jače podržavala slobodu i jednakost ljudske vrste. Ono što je zajedničko svim tim dimenzijama pitanja su o isključivanju i uključivanju: (1) normativna se dimenzija pita koja su filozofska opravdanja za isključivanje ili uključivanje nekoga iz jedne političke zajednice; (2) sociološka se dimenzija pita što stvara i podržava isključiv i uključiv sustav država; (3) prakseološka dimenzija pita se kakav utjecaj uključiv i isključiv sustav imaju na ljudsko djelovanje (Linklater, 1992). Prema kritičkoj teoriji, ta trodimenzionalna metoda omogućuje superiorno razumijevanje međunarodnih odnosa. Štoviše, kritička teorija međunarodnih odnosa nastoji »ponovo ujediniti međunarodne odnose pod vodstvom kritičke teorije... ukazivanjem na pojedine prednosti različitih pristupa te pokazujući kako se oni mogu međusobno približiti«. Ona posjeduje »viziju međunarodnih odnosa koja, potpunije artikulirana, može usmjeriti čitavo polje « (Linklater, 1992, 79). No čini se da taj kritički obrat u međunarodnoj teoriji ipak nikad nije opravdao svoj naziv te postao dominantan među teorijama međunarodnih odnosa.

\section{Zaključak}

Ako prihvatimo Coxovu poznatu podjelu na problem solving teorije i kritičke teorije, svijet suočen s mnoštvom problema vjerojatno će dati prednost teorijama koje mogu dati dobro objašnjenje o tome što se to trenutačno događa u svijetu i, eventualno, ponuditi načine rješavanja tih problema. Kritičke se teorije međunarodnih odnosa, s druge strane, teško mogu iskoristiti u tu svrhu. Transformacije političke zajednice koje sugeriraju kritičke teorije čine se nepraktičnim, a ponekad i previše radikalnim načinom rješavanja nagomilanih međunarodnih problema. Barem što se tiče onih koji donose odluke u međunarodnim odnosima, kao i onih koji bi iste trebali savjetovati. Uz to, kritička je teorija veoma kompleksna teorija, temeljena na mnoštvu različitih pretpostavki koje su još uvijek daleke načinu razmišljanja glavnih donositelja odluka u međunarodnim odnosima. Čak je i znanstvenicima koji se bave međunarodnim odnosima teško nositi se sa slože- 
nošću misli kritičkih teoretičara. Primjerice, Waltz je u svojoj reakciji na kritiku koju mu je napisao Ashley (1986) odgovorio da je čitanje njegovih (Ashleyevih) djela poput ulaženja u labirint, »nikad ne znam točno gdje sam i kako ću, i hoću li uopće, izići« (Waltz, 1986, 337). Štoviše, pozitivisti poput neorealista tvrde da nastoje podatcima poduprijeti svoje tvrdnje, a za kritičke teoretičare kažu da se često u postupku opravdanja svojih tvrdnji pozivaju na druge mislitelje, u prvom redu na pripadnike svoje tradicije mišljenja, a bez podupiranja svojih tvrdnji podatcima iz stvarnoga svijeta.

Iako, bez sumnje, kod većine ljudi postoji želja za pravednijim i boljim svijetom, teško je iz realističke perspektive zamisliti kako se svijet može promijeniti koristeći pristup koji sugerira kritička teorija. Razotkrivanje moralnih nesavršenosti postojećih političkih zajednica ne znači automatski da se iste mogu popraviti pomoću recepata kritičke teorije. Ako je dvojba stabilnost ili emancipacija, čemu dati prioritet? Treba li žrtvovali sigurnost i stabilnost, stavivši emancipaciju na prvo mjesto? Treba li odabrati emancipaciju ili sigurnost? Naravno, odgovor nije crno-bijel, jer se stabilnost i emancipacija ne moraju međusobno isključivati, ali pitanje je do koje smo mjere spremni ići u narušavanju sigurnosti i stabilnosti da bismo emancipirali marginalizirane skupine. S druge strane, u kojoj smo mjeri spremni kontrolirati druge kako bismo sebi sami zajamčili sigurnost?

Ostaje nam odgovoriti na pitanje koje smo postavili na početku, odnosno je li kritička teorija međunarodnih odnosa kakvu zastupa Linklater etički i/ili pristupom superiorna Waltzovu neorealizmu? Ako se procjenjuju različiti ciljevi neorealizma i kritičkih teorija, onda bismo mogli reći da su ti ciljevi gotovo nesumjerljivi: neorealizam ima za cilj objasniti ponašanje države u anarhijskom sustavu, a kritičke teorije nastoje otkriti način na koji se može ostvariti što veća emancipacija. Iz toga proizlazi i razilaženje u pristupu međunarodnim odnosima: neorealizam nastoji otkriti kako stvari jesu, a kritičke teorije nastoje pokazati i kakve bi stvari trebale biti. To rezultira razlikama u predmetima, postupcima dokazivanja, pretpostavkama i načinu razmišljanja općenito. Nadalje, unatoč tomu što se realizam često povezuje s ciničnom i amoralnom politikom moći, a kritičke teorije s etikom, teško je utvrditi etičku superiornost kritičke teorije. Neorealizam se, više-manje, zadržava na području onoga što se u zadanim okolnostima mora i može učiniti, a da se pritom ne umanjuje sigurnost, neovisnost i prosperitet država. Zato se realizam sam često doživljava kao perspektiva koja otkriva područje nužnosti u međunarodnoj politici te daje opravdanja poput: "Nije važno što mi želimo i trebamo učiniti — važno je što moramo i možemo učiniti!" Kritičke teorije, s druge strane, insistiraju na tome da treba krenuti korak dalje i promatrati što u okviru toga što se "može" učiniti i "treba" učiniti kako bismo povećali područje slobode i autonomije svakoga pojedinca i zajednice. No, sam cilj kritičke teorije međunarodnih odnosa, a to je emancipacija, ne čini je nužno etički superiornom neorealizmu. Etičko je pravilo da "treba" pretpostavlja "može", s time da se realisti često zadržavaju na "mora", ograničavajući svoje područje toga što se "može", kako bi očuvali iste sposobnosti djelovanja (moć). S druge strane, kritički teoretičari više naglašavaju "treba", s time da se to njihovo 
"treba" temelji na još neostvarenom "može", odnosno na formi buduće političke zajednice koja će omogućiti moralno poželjnu emancipaciju. Primjerice, realisti ne žele niti zagovaraju rat — osim u iznimnim slučajevima. Nadalje, realisti cijene slobodu svojih političkih zajednica, cijene slobodu pojedinaca u političkim zajednicama, te ponekad traže načine kako se boriti protiv dominacije drugih i na unutarnjem i na vanjskopolitičkom planu (barem zastupnici škole ravnoteže moći). Štoviše, realisti vjeruju da daju dobre savjete kako spriječiti rat ili, u slučaju nemogućnosti izbjegavanja rata, kako i kad ratovati. Prihvaća se nesavršenost sustava država i nastoji se otkriti kako preživjeti u njemu — odnosno prilagoditi svoje želje zbilji. S druge strane, dobre namjere bez uzimanja zbilje u obzir rijetko dovode do dobrih rezultata. Ako stavljamo naglasak ne na lijepe želje, nego na zbiljske rezultate, onda vidimo da emancipacija, kao hvalevrijedan cilj, ne znači uvijek i moralno superioran cilj — u smislu da ćemo mu dati prioritet nad mirom i sigurnošću. U konačnici, realisti isto mogu željeti slobodu i autonomiju svakoga pojedinca, ali u suočavanju sa zbiljom ipak misle da moraju dati prednost okolnostima. Moralni ciljevi kritičkih teoretičara i realista ne moraju se razlikovati. Ono što ih razlikuje to je što kritički teoretičari vjeruju da je emancipacija ostvariva, a realisti su puno skeptičniji prema tome. Sve se svodi na pitanje treba li stati kod zadanih okolnosti i nastojati se na najbolji mogući način (racionalno) prilagoditi istima, ili treba nastojati, pomoću razuma, morala, maštovitosti i spremnosti na žrtve, prepoznati mogućnosti razvoja svjetske politike u smjeru veće emancipacije. No potpuna povijest razvoja ljudske slobode može se pisati samo nakon što je isti završio.

\section{Literatura}

Cox, R.W. (1986). Social forces, states and world orders: Beyond international relations theory. U: Robert Keohane (ur.), Neorealism and Its Critics (str. 204-254). New York: Columbia University Press.

Devetak, Richard (2009). Critical Theory. U: Scott Burchill et al. (ur.), Theories of International Relations (str. 159-182). Basingstoke: Palgrave MacMillan Burchill.

Linklater, Andrew (1981). Men and citizens in international relations. Review of International Studies, 7(1), 23-37.

Linklater, Andrew (1990). Beyond Realism and Marxism: Critical Theory and International Relations. Basingstoke: MacMillan.

Linklater, Andrew (1992). The question of the next stage in international relations theory: A critical-theoretical point of view. Millennium: Journal of International Studies, 21(1), 77-98.

Linklater, Andrew (1998). The Transformation of Political Community. Cambridge: Polity Press.

Linklater, Andrew (1999). Transforming political community: A response to the Ccritics. Review of International Studies, 25(1), 165-175.

Linklater, Andrew (2005). Dialogic politics and the civilising process. Review of International Studies, 31(1), 141-154.

Schweller, Randall L. (1999). Fantasy theory. Review of International Studies, 25(1), 147-150. 
Waltz, Kenneth (1979). Theory of International Politics. Reading: Addison-Wesley Publishing Company.

Waltz, Kenneth (1986). Reflections on theory of international politics. A response to my critics. U: Robert Keohane (ur.), Neorealism and Its Critics (str. 323-345). New York: Columbia University Press.

Waltz, Kenneth (1990). Realist thought and neorealist theory. Journal of International Affairs, 44 (spring/summer), 21-37.

Waltz, Kenneth (2000). Structural realism after the Cold War. International Security, 25(1), 5-41.

\section{Critical Theory in International Relations and Neorealism}

\section{Damir Mladić*}

\section{Summary}

In this article, the author compares Andrew Linklater's critical international theory with Kenneth Waltz's neorealism (structural realism). The two theories are compared primarily in regard to their moral features and in their approach to international relations. Since Linklater claims that the critical theory in international relations is morally superior to structural realism as well as to other international relations theories, the author examines it to determine whether there are justified reasons for such claims. There is a difference between the main goals of critical international theory and neorealism, and it is difficult to determine which goal is morally more desirable: promoting national interests, survival and stability of the state system, or emancipation which presupposes desirable but non-existing models of political community and transformation of the existing international state system. In the existing political world, finding solutions to pressing problems seems to have priority over suggestions by critical theories on resolving these problems through the transformation of our political communities. The author concludes that there is no decisive reason for claiming that critical international theory is superior to neorealism.

Key words: critical international theory; neorealism; ethics; political community; emancipation

* Damir Mladić, Ph.D., Senior Assistant Professor, Libertas International University. Address: Trg J. F. Kennedyja 6b, 10000 Zagreb, Croatia. E-mail: dmladic@libertas.hr 